Bacher, Muhammedanische Weissagungen im A. T. 309

\title{
Muhammedanische Weissagungen im Alten Testamente.
}

$\mathrm{Zu}$ den unter obigem Titel veröffentlichten Mittheilungen Brockelmanns (Bd. XV, S. $138 \mathrm{ff}$.) seien mir folgende Bemerkungen gestattet.

Zu S. 140, Z. 4. Ibn Kִuteiba giebt איים Jes. 42, 10, 12 mit جن wieder. Br. nennt diese Uebersetzung * interessant *, unterlälst es aber, eine Erklärung für dieselbe zu geben. Wenn man annehmen dürfte, was $\mathrm{Br}$. im nächsten Absatze in Bezug auf Deuteron. 33, 12 thut, dals Ibn Kuteiba irgendwie auch das Targum benutzt hat, so läge es nahe, daran zu denken, dals جن auf נגון (aram. Uebers. von איים, Inseln) zurückgeht. Doch ist eine solche Annahme fast ausgeschlossen, Richtiger ist es anzunehmen, dafs in Ibn Kuteiba's Quelle in Jes. 42, 10 und 12 ebenso übersetzt war, wie es in der Peschițtha zu Jer.

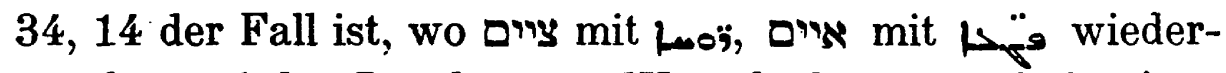
gegeben wird. Das letztere Wort bedeutet auch im Aramäischen und Neuhebräischen Dämonen, Plagegeister. S. Targ. II zu Ester 1, שיר של פגעים ; שדין ופגעין, Name des 91. Psalms (als Schutzes gegen die Dämonen), s. Levy IV, 7 b. In Jes. 13, 22 übers. P. אמין mit,

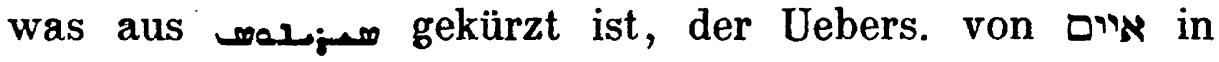
Jerem. 50, 39 (wo ציים unübersetzt geblieben ist). Die LXX übersetzt in Jes. 13 und 34 mit bvoxéviaupor (ebenso Vulgata zu Jes. 34 onocentauri), wohl Dämonen 
in Affengestalt. Die mythischen Gestalten der "Sirenene, welche - als Dämonen gedacht - P. für איים giebt, gebraucht LXX zur Wiedergabe von תנים, Jes. 34, 13; ebenso Vulgata zu Jes. 13, 22: sirenes = תנים. Eine andere Mythengestalt wird in der Vulgata Jerem. 50, 39 zur Wiedergabe von איים benutzt, nämlich fauni ficarii. Die LXX übers. an der letzteren Stelle איים mit »Inseln*

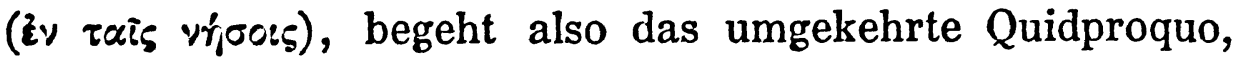
wie die Quelle oder der Gewährsmann Ibn Kuteiba's zu Jes. 42 .

Ib. Z. $8 \mathrm{ff}$. Die Angaben I. K.'s über die ssyrische Uebersetzung * und den shebräischen Text von Deut. 33, 12 werden durch die Vermuthung Br.'s nicht verständובין כתפיו Wenigstens für den hebräischen Text. (2) erlaube ich mir eine Vermuthung auszusprechen. Die hebräischen Worte sollen bedeuten: "Auf seinen Schultern ist das Zeichen der Prophetie *, eine Anspielung auf das bekannte Prophetenmal Muhammed's. Vielleicht deutete der Gewährsmann Ibn K.'s שיגנון mit, signum, Zeichen. Im Neuhebräischen ist dieses Wort sehr gebräuchlich, s. Levy III, 476 b.

Ib. Z. 9 von unten. Brockelmann ist es nicht gelungen, das Psalmencitat: ,Gott sandte den Gesetzgeber, damit die Leute wüfsten, dafs er ein $M_{e n s c h}^{6}$ zu verificiren*. Das Citat ist eine leichte Umdeutung von Ps. 9, 21, auf Grund der übereinstimmenden Uebersetzung der LXX, P. und Vulg. (Vulgata: Constitue, Domine, legislatorem super eos: ut sciant gentes, quoniam homines sunt). Diese Uebersetzung beruht auf der Lesung מירתה für מרָin. Ibn .Kuteiba's Gewährsmann setzte statt des Imperativs das Perfectum (oder las vielleicht so in der ihm vorliegenden Uebersetzung) und verwandelte den Plural von אנוש המה in den Singular.

lb. Z. 4 von unten. Die Deutung von רכב גמל, Jes. 21, 7, auf Muhammed und von רכב חמור, ib., auf den 
Messias findet sich auch, in sehr merkwürdiger Form, bei keinem Geringeren als Moses Maimûnî. In seinem Sendschreiben an die Juden Südarabiens (אגרת תימן, ed. D. Holub, Wien 1873, S. 44) sagt er, רכב חמור bedeute nach Zacharia 9, 9 den Messias, dessen Ankunft durch das Auftreten Muhammeds, des רוכב על גמל והוא מלך הערב) רכב גמל (רחל), vorbereitet sei.

S. 141, Z. 6 von unten. «Siehe, ich gründe in Zion, d. i. im Hause Gottes, einen Stein in einer geehrten Ecke*. Diese Jesaia-Stelle, in welcher Ibn Kuteiba den heiligen Stein dẹr Kâba erwähnt findet, und welche Br. nicht nachweisen kann, ist 28, 16: הנני יסר בציון אכן ... פנת יקרת. Der Uebers. Ibn Kuteibas's scheint die der P. zu Grunde

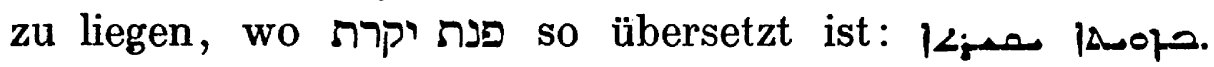

S. 142, Z. 3. Die Frage *wo? * beantworte ich mit: Jesaia 35, 2: כבוד הלבנון נתן לה הדר הכרמל - Ib., Z. 15: "sie werden geschlagen werden u. s. w. * Das ist eine Wiedergabe von Jes. 21, 15, wo auch die Beziehung auf die Araber im Texte (V. בערב 13) gegeben ist.

W. Bacher. 